\title{
Effects of the American oyster Crassostrea virginica on growth rates of the seagrass Halodule wrightii
}

\author{
Dale M. Booth ${ }^{1,2,3, *}$, Kenneth L. Heck Jr. ${ }^{1,2}$ \\ ${ }^{1}$ Dauphin Island Sea Lab, 101 Bienville Blvd., Dauphin Island, Alabama 36528, USA \\ ${ }^{2}$ Department of Marine Science, University of South Alabama, Mobile, Alabama 36688, USA \\ ${ }^{3}$ Present address: Center for Environmental Studies, Horn Point Laboratory, 2020 Horns Point Road, University of Maryland, \\ Cambridge, Maryland 21613, USA
}

\begin{abstract}
American oysters Crassostrea virginica have significant effects on ecosystem structure and function and may potentially determine whether coastal systems are dominated by either benthic or pelagic primary production. Field experiments were used to determine the effect of oyster density on the abundance and growth rate of shoalgrass Halodule wrightii in Mississippi Sound, Alabama, USA. Oysters were deployed at densities of $0,15,75$, and 150 ind. $\mathrm{m}^{-2}$ in $1 \mathrm{~m}^{2}$ plots of $H$. wrightii in September 2004. Changes in shoalgrass shoot density, growth rate, total suspended solids (TSS), porewater nutrients, light transmittance, and epiphyte loads were all measured from OctoberNovember 2004, and June-July 2005. Results showed no significant relationship between oyster density, light transmittance, TSS, or epiphyte loading. However, there was a significant positive relationship between oyster density and porewater $\mathrm{NH}_{4}$ and $\mathrm{PO}_{4}$. Seagrass growth rates were highest at intermediate oyster densities, while high oyster densities negatively affected growth rates, shoot density, and plant biomass.
\end{abstract}

KEY WORDS: Halodule wrightii $\cdot$ Submerged aquatic vegetation $\cdot$ SAV-oyster interactions $\cdot$ Growth rate $\cdot$ Habitat restoration

\section{INTRODUCTION}

\section{Bivalve ecosystem services}

The decline in oyster populations on the east coast of the United States has focused much attention on the importance of the ecological services that oysters provide by maintaining estuarine ecosystem stability and in facilitating production through other organisms. Oysters play a role in determining water clarity, nutrient cycling, and community composition (Dame 1979, Dame et al. 1980, 1989, Newell \& Koch 2004), and Newell (1988) hypothesized that oyster-depleted bays are more likely to be susceptible to eutrophication and episodes of hypoxia than bays with healthy oyster populations.

Filter-feeding bivalves may enhance benthic productivity via several mechanisms: (1) altering sediment nutrient concentrations, (2) stabilizing bottom sedi- ments, (3) increasing light penetration, (4) decreasing leaf epiphyte loads (Biggs \& Howell 1984, Dame et al. 2001, Peterson \& Heck 2001a,b).

Bivalves excrete nutrients by filtering suspended material and binding it into dense biodeposits that sink to the sediment surface. These biodeposits enrich sediment porewater (Reusch et al. 1994, Peterson \& Heck 2001a, Newell et al. 2002), which is the most important source of nutrients for seagrasses (Fourqurean et al. 1992a,b). Bertness (1984) showed that increased densities of the mussel Geukensia demissa resulted in higher soil nitrogen levels. This stimulated production by associated Spartina alterniflora, which displayed increased above- and belowground biomass. Examples of enhanced plant growth in the presence of bivalves also exist in aquatic systems; Posey et al. (1993) showed that interactions between clams and the introduced submerged aquatic vegetation (SAV) Hydrilla verticil- 
lata resulted in increased plant length, as well as greater plant branching.

In addition to enriching nutrients in porewater and sediment, bivalves also influence physical sediment dynamics, prevent erosion and increase sedimentation rates (Bertness 1984), and thereby may facilitate the establishment of recruits as well as the retention of SAV. Adult Crassostrea virginica can produce approximately $1.6 \mathrm{~g}$ of biodeposit per animal per week, and can deposit seston at a rate 7 times faster than the rate of sedimentation via gravity alone (Haven \& MoralesAlamo 1966), leading to enhanced sediment stability. This should result in higher seagrass recruitment success by maintaining bed integrity against the processes of erosion, and so give seedlings a chance to become established without being buried or scoured by sediment movement.

The presence of oysters also increases habitat complexity, and a variety of organisms exploit the interstitial spaces on oyster reefs, as well as the mud that accumulates in crevasses (Dame 1979, Breitburg et al. 1995). Epiphyte grazers may utilize bivalves as a predation refuge, leading to an indirect benefit for associated seagrasses as epiphyte loads on the grass blades are decreased through grazing (Peterson \& Heck 2001b). Because epiphytes growing on grass leaves may reduce productivity by decreasing leaf light absorption, additional grazers could potentially yield a positive seagrass response (Orth \& van Montfrans 1984, Peterson \& Heck 2001b).

Oysters also improve water clarity by removing particles of a diameter of $>3 \mu \mathrm{m}$ from the water column; these can either then be assimilated or excreted in a dense mucus-bound deposit which may then become incorporated into the sediment rather than being resuspended in the water column (Newell 1988, Nelson et al. 2004). This may benefit SAV by reducing phytoplankton populations and suspended sediment, which would otherwise decrease light transmission to the benthos.

\section{Study organism}

Halodule wrightii, known as shoalgrass, is commonly found in the subtropical waters of the Atlantic, Caribbean, and the Gulf of Mexico. Where it is abundant, shoalgrass contributes a large percentage of total benthic primary production (Morgan \& Kitting 1984), and because of its relatively small rhizome storage capacity, it is particularly sensitive to changes in light intensity, nutrients, and water circulation (Hauxwell et al. 2001). This responsiveness of shoalgrass to physical parameters in its environment makes it a useful indicator of changes in water quality.
Nutrients play a key role in the production of shoalgrass; a study of nutrient enrichment in Florida Bay, where sediment nutrient concentrations of phosphorus and nitrogen were elevated via bird guano, demonstrated an increase in areal production of Halodule wrightii by 3 orders of magnitude over 2 yr (Powell et al. 1989). Results also showed that $H$. wrightii contained elevated levels of nitrogen and phosphorous in both shoots and rhizomes. Whether nitrogen or phosphorus is the limiting nutrient for $H$. wrightii varies and may depend on the region and the type of sediment (Fourqurean et al. 1992b). Williams (1990) indicated that tropical seagrass beds seemed limited by nitrogen availability, while more recent work indicates that phosphorus plays the greater role in tropical and subtropical regions. For example, Fourqurean et al. (1992a) found a positive relationship between soluble porewater reactive phosphorus, and standing crops of Thalassia testudinum (the dominant seagrass in Florida Bay). Further studies in Florida Bay found evidence that supports P-limitation in T. testudinum, with increased $\mathrm{C}: \mathrm{P}$ and $\mathrm{N}: \mathrm{P}$ ratios when within close proximity to a nutrient source (Fourqurean et al. 1992a,b). In contrast, $\mathrm{C}: \mathrm{N}$ ratios did not vary, leading the authors to conclude that the system is P-limited and N-saturated. In estuarine systems, $\mathrm{N}$-limitation is accepted as the most common occurrence (Howarth \& Marino 1988, Howarth et al. 1988). However, studies in the northern Gulf of Mexico show that P-limitation may play the greater role in seagrass systems (Johnson et al. 2006).

This study tested the hypothesis that Crassostrea virginica enhances growth rates of the seagrass Halodule wrightii. The direct response of the plants to oyster addition was quantified by measuring growth rate, shoot density, and biomass; effects of oysters on the physical environment were also measured in order to determine the mechanisms of impact on seagrass growth.

\section{MATERIALS AND METHODS}

Study site. The study site was located in the northern Gulf of Mexico (AL, USA), along the western shore of Point Aux Pines (PAP). Seagrass beds in this area tend to be dominated by Halodule wrightii during the summer, but Ruppia maritima (widgeongrass) also occurs. Low densities of Crassostrea virginica are also found in this area.

Experimental design. Treatments consisted of 4 densities of adult oyster (zero, low, intermediate, and high), that were established in 2 spatially separated blocks within an existing grass bed. High density oyster treatments (150 oysters $\left.\mathrm{m}^{-2}\right)$ were intended to sim- 
ulate peak populations as historically recorded in nearby Mobile Bay (May 1971). The intermediate density used in this study was 75 oysters $\mathrm{m}^{-2}$, and the low density was 15 oysters $\mathrm{m}^{-2}$. This range was chosen to cover an order of magnitude and also to maintain any treatment effects in the event of minor oyster mortality. Five replicates of each oyster density were used in each block, as well as 5 control plots containing no oysters, to make a total of 40 plots.

Oysters were collected from stocks in Mississippi Sound by a local contractor, and were deployed individually, rather than in clumps. To ensure that rates of filtration between replicates were the same, adult oysters of similar size (approximately $7.62 \mathrm{~cm}$ in length) were used throughout (Powell et al. 1992). For each density, bivalves were evenly distributed throughout the plot, with shells lying flat on the sediment surface. As the plots were in an established grass bed, this meant that the oysters were placed directly on top of pre-existing shoots. It was expected that the oysters could kill shoots directly beneath them, but that those shoots growing among the bivalves would benefit, showing enhanced growth rates.

Treatments were placed in $1 \mathrm{~m}^{2}$ plots, with edges delineated by a PVC frame that was anchored in the sediment using rebar. Plots were set out in 4 rows of 5 within each block. Rows were separated by $1 \mathrm{~m}$, and each plot was separated from its neighbor by at least $1 \mathrm{~m}$. Each plot in a row was randomly assigned an oyster density. The seagrass rhizomes were severed at the edge of each plot with a shovel to prevent nutrients from passing into or out of the plot via rhizome translocation.

Quantifying plant responses. Seagrass growth rates were determined using the shoot clipping technique of Hauxwell et al. (2001). This involved clipping the shoots just above the sheath/blade interface and then harvesting 1 to $2 \mathrm{wk}$ later. It is important to note that clipping underestimates the growth rate of Halodule wrightii by 38 to $56 \%$ (Hauxwell et al. 2001) due to the removal of a large percentage of photosynthetically active material (Morgan \& Kitting 1984, Tomasko \& Dunton 1995, Hauxwell et al. 2001). However, it is a useful method in determining relative differences in growth rate, especially in systems where visibility is limited, and where plants are small.

Starting in October 2004, growth rate data were collected twice a month. Experimentation continued through to late November as long as grass persisted, and was then repeated in June and July 2005 to assess seasonal variation. All shoots within $0.01 \mathrm{~m}^{2}$ quadrats were clipped, and the quadrats marked with orange construction flags. Grass was allowed to grow for 1 to 2 wk, after which shoots from the clipped areas were harvested and transported to the laboratory for analy- sis. Shoot density and number of leaves in the clipped areas were determined, and the width and length of each leaf were measured. Shoot growth rate $\left(\mathrm{mm}^{2}\right.$ shoot $^{-1} \mathrm{~d}^{-1}$ ) was determined by summing the total leaf area (leaf width $[\mathrm{mm}] \times$ leaf length $[\mathrm{mm}]$ ) on a shoot, and dividing this by the number of days since clipping (Hauxwell et al. 2001). This number was then multiplied by the number of shoots $\mathrm{m}^{-2}$ to calculate leaf production rate.

To estimate treatment effects on above- and belowground biomass, cores were taken from each plot (October and December 2004, and June and July 2005). Cores ( $7.62 \mathrm{~cm}$ diameter) were sieved to remove sediment and then sorted in the laboratory to separate the 2 grass species (Halodule wrightii and Ruppia maritima), as well as the above- and belowground biomass portions. Ash-free dry weights were then obtained for the isolated biomass components.

In the 2005 sampling period, 10 to 20 shoots were collected twice a month to determine whether seagrasses took up increased amounts of nitrogen and phosphorous in the oyster treatments. Leaves were scraped clean of epiphytes, dried at $80^{\circ} \mathrm{C}$, and then ground with mortar and pestle. Nitrogen and carbon contents of the blades were measured using a CarloErba NA1500 CNS analyzer (Sharp 1974). Phosphorus levels in the tissue samples were determined using the standard wet chemical technique of Fourqurean et al. (1992a) and Soloranzo \& Sharp (1980). Ratios of C:P and C:N were then calculated.

Quantifying oyster impact. To determine if oysters affected turbidity, water samples were taken (in October 2004, February 2005, and June 2005) in order to measure total suspended solids (TSS). A $60 \mathrm{ml}$ syringe was used to collect $\sim 50 \mathrm{ml}$ of water from directly above the seagrass canopy in each plot. Suspended material was filtered using pre-weighed GF/F filters, and dry weights obtained. TSS $\left(\mathrm{g} \mathrm{ml}^{-1}\right)$ was determined by dividing the weight of dried material by the volume filtered. Light availability was also quantified by measuring the percentage light transmittance reaching the seagrass canopy using a spherical cell Li-COR 1000 (monthly measurements were taken in October 2004, and in January, February, and March 2005). In situ water readings were taken from the water column, directly above the top of the seagrass canopy.

Sediment nutrient levels were measured to see if oysters significantly affected the concentrations of nitrogen and phosphorus available to seagrass. Porewater samples were collected from the center of each plot (1, 5, and 9 mo after oyster deployment). Liquid and sediment $(20 \mathrm{ml})$ was drawn into a syringe (extended with a $10 \mathrm{~mm}$ perforated plastic tip), placed directly into an acid-washed centrifuge tube, and transported on ice back to the laboratory. After cen- 
trifuging the sample to remove solids, the liquid portion was analyzed for total nitrogen and phosphorus levels using a Skalar auto-analyzer.

To determine if sulfide was accumulating in the plots due to organic input from the oysters, $2.5 \mathrm{~cm}$ diameter cores were taken from each control $\left(0\right.$ oysters $\left.\mathrm{m}^{-2}\right)$ and high (150 oysters $\mathrm{m}^{-2}$ ) density treatment. Sulfide rapidly oxidizes on contact with air, so effort was made to minimize contact between the samples and an oxygenated environment by sealing them in the corer as soon as they were removed from the sediment. Samples were transported back to the laboratory on ice, where they were transferred into $50 \mathrm{ml}$ centrifuge tubes, spun, and the liquid separated. The liquid was passed through a GF/F filter, and then fixed with a $2 \%$ zinc acetate solution $(\sim 30 \mu \mathrm{ln}$ Acetate to each $1 \mathrm{ml}$ of sample). Sulfide was then measured spectrophotometrically using the methylene blue method of Cline (1969).

Before drying leaves for nutrient analysis, epiphytes were removed to estimate leaf-epiphyte loading. For each shoot collected, epiphytes were scraped from the oldest leaf, and the leaf area was then determined through measurement of leaf length and width. Removed epiphytes were dried in pre-weighed pans, and a dry weight obtained. Epiphyte load $\left(\mathrm{g} \mathrm{mm}^{-2}\right)$ was calculated by dividing epiphyte dry weight, by 2 times the product of leaf width $(\mathrm{mm})$ and leaf length $(\mathrm{mm})$.

Statistical analysis. All data were checked for the assumptions of normality and homogeneity of variance. Where these assumptions were violated, data were transformed in order to meet these assumptions.

A 2-way blocked ANOVA was performed to determine the effect of oyster density on the growth rate and shoot density of Halodule wrightii using oyster density and date as predictors. Blocks were analyzed separately due to a significant interaction between date and block under a 3-way ANOVA. Oyster density effects on $H$. wrightii biomass were analyzed using a 3-way blocked ANOVA with oyster density, date, and block used as predictors. Data from both seasons were pooled for the analysis.

Total suspended solids $\left(\mathrm{g} \mathrm{ml}^{-1}\right)$ and light transmittance $(\%)$ were analyzed using a 3 -way blocked ANOVA using oyster density, date, and block as predictors. No significant interactions were noted, so data from all sampling dates and blocks were pooled. Epiphyte loads were analyzed using a 3-way ANOVA with all data pooled, and with oyster density, date, and block used as predictors.

Effects of oyster density on porewater concentrations of ammonium $\left(\mathrm{NH}_{4}\right)$, and phosphate $\left(\mathrm{PO}_{4}\right)$, were analyzed using a 3-way blocked ANOVA with oyster density, block, and date used as predictors. Data were pooled and analyzed by individual dates to assess effects over time. Tukey's test was then used to determine pair-wise differences. To analyze sulfide concentrations, a 1-way ANOVA was used to determine the effect of oyster presence ( 0 versus 150 oysters $\mathrm{m}^{-2}$ ).

A 3-way blocked ANOVA was used to determine the effects of oyster density, date, and block on seagrass nutrient content ( $\mathrm{C}: \mathrm{N}, \mathrm{C}: \mathrm{P}, \mathrm{N}: \mathrm{P})$. All data between seasons and blocks were pooled for this analysis.

\section{RESULTS}

\section{Plant responses}

Growth rates in Block 1 for the fall of 2004 (Fig. 1) showed significant effects of both oyster density $(p=$ $0.001)$ and date $(p=0.000)$. Tukey's test revealed that a low oyster density (15 oysters $\mathrm{m}^{-2}$ ) produced growth rates significantly higher than the control $(0$ oysters $\left.\mathrm{m}^{-2}\right)$ and high density $\left(150\right.$ oysters $\left.\mathrm{m}^{-2}\right)$ treatments $(\mathrm{p}=$ 0.008 and 0.0016 , respectively), but was not different from the medium density $\left(75\right.$ oysters $\mathrm{m}^{-2}$ ) treatment. Medium density treatments were not significantly different from the control and high density treatments ( $p>0.05)$. The actual mean growth rate in the low density treatment was more than double the mean growth rate in the control (Fig. 1). Over time, growth rate increased significantly from 14 to 29 October 2004, and 29 October to 9 November 2004 ( $p<0.05)$. Growth rates then decreased significantly from 9 to 23 November $2004(p=0.000)$, most likely as a result of natural seasonal declines in grass growth rates.

In Block 2 for the fall of 2004 (Fig. 1), there were again significant effects of both oyster density ( $p=$ $0.01)$ and date $(p=0.001)$. Tukey's test revealed that the medium density treatment showed a significantly higher growth rate than the control and low density treatments $(\mathrm{p}=0.0087$ and 0.0483 , respectively). The mean growth rate in the medium density treatment was nearly twice that of the control, but was not significantly different to the high density treatment. When analyzed by date, growth rate decreased over time, again most likely as a result of seasonal decline.

In the spring of 2005 (Fig. 1), there were significant effects of both oyster density $(p=0.000)$ and date $(p=$ 0.036 ). There was a nearly total loss of seagrasses in the high density oyster treatments in Block 1; so while there were no significant differences between control, low and medium density treatments $(p>0.05)$, growth rates in the high density plots were significantly lower than in all other treatments $(p=0.000)$. Tukey's test showed that most dates were not significantly different; however, growth rates measured on 13 July 2005 were significantly higher than those on 7 July 2005 ( $p=$ 0.0511). 

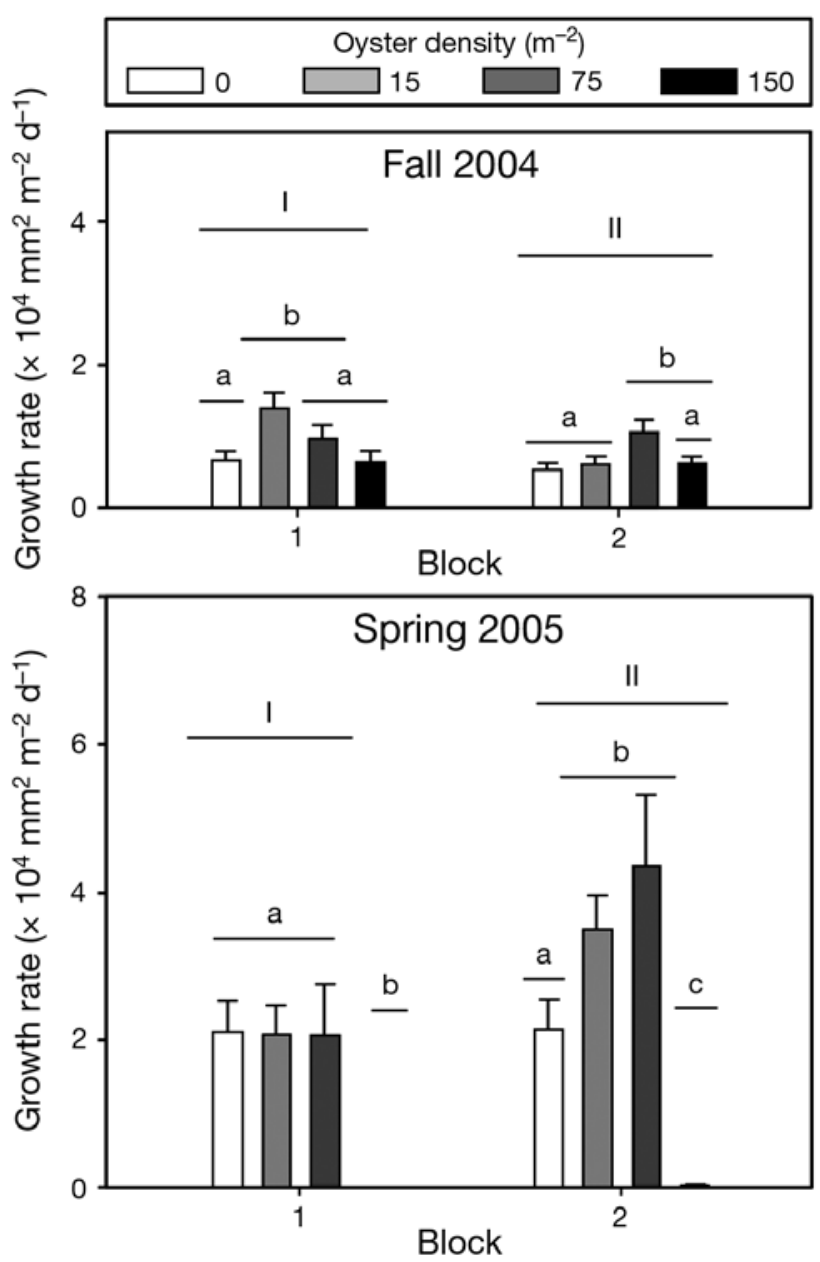

Fig. 1. Halodule wrightii. Growth rates $\left(\mathrm{mm}^{2} \mathrm{~m}^{-2} \mathrm{~d}^{-1}\right)$ from fall of 2004 and spring 2005 for each oyster density (mean + SE). Roman numerals indicate significant differences $(p<0.05)$ between study areas (Blocks 1 and 2); letters indicate significant differences among oyster density treatments. Within each study block, dates were pooled for the post hoc comparisons

For Block 2 in the spring of 2005 (Fig. 1), there was a significant effect of oyster density $(p=0.000)$, date $(p=$ 0.000 ), and also a significant interaction between oyster density and date ( $p=0.003)$. Tukey's test showed that the control treatment was significantly lower than the low and medium treatments $(\mathrm{p}=0.0190$ and 0.0016 , respectively), but significantly higher than the high density treatment $(p=0.000)$. Medium and low density treatments were not significantly different from each other $(p=0.846)$, but both were significantly higher than the high density treatment $(p=0.000)$. There was no significant difference between growth rates measured on 16 June 2005, 27 June 2005, and 5 July 2005 ( $p$ > 0.05), but growth rates on 13 July 2005 were significantly higher than all earlier sampling dates $(\mathrm{p}<0.002)$.
Aboveground Halodule wrightii biomass (Fig. 2) showed a significant effect of oyster density $(p=0.000)$, date $(p=0.000)$, and block $(p=0.000)$. The measured biomass in Block 1 was significantly lower than that in Block $2(p=0.000)$, but the trends within blocks were similar, and as such were pooled together for post hoc comparisons. The aboveground biomass component was significantly higher in control treatments when compared to low, medium, and high density treatments ( $p=0.0415,0.000$, and 0.000 , respectively). There was no significant difference between medium and low density treatments $(p=0.0583)$, and biomass was significantly increased in the medium density treatment as compared to the high ( $\mathrm{p}=0.0173)$. The belowground component (Fig. 2) responded similarly, with significant effects of oyster density $(p=0.000)$, date $(p=0.000)$, and block $(p=0.003)$. Tukey's test showed that belowground biomass for Block 1, was again lower than Block $2(\mathrm{p}=0.0026)$. Control treatments were not significantly different from the low density treatments $(p=0.422)$, but were significantly higher than at medium and high oyster densities $(\mathrm{p}=$ 0.032 and 0.000 , respectively). Low and medium density treatments were not significantly different from each other, but both were significantly higher than the high density treatments $(p=0.0021)$. Medium and high density treatments were not significantly different $(\mathrm{p}>0.05)$.

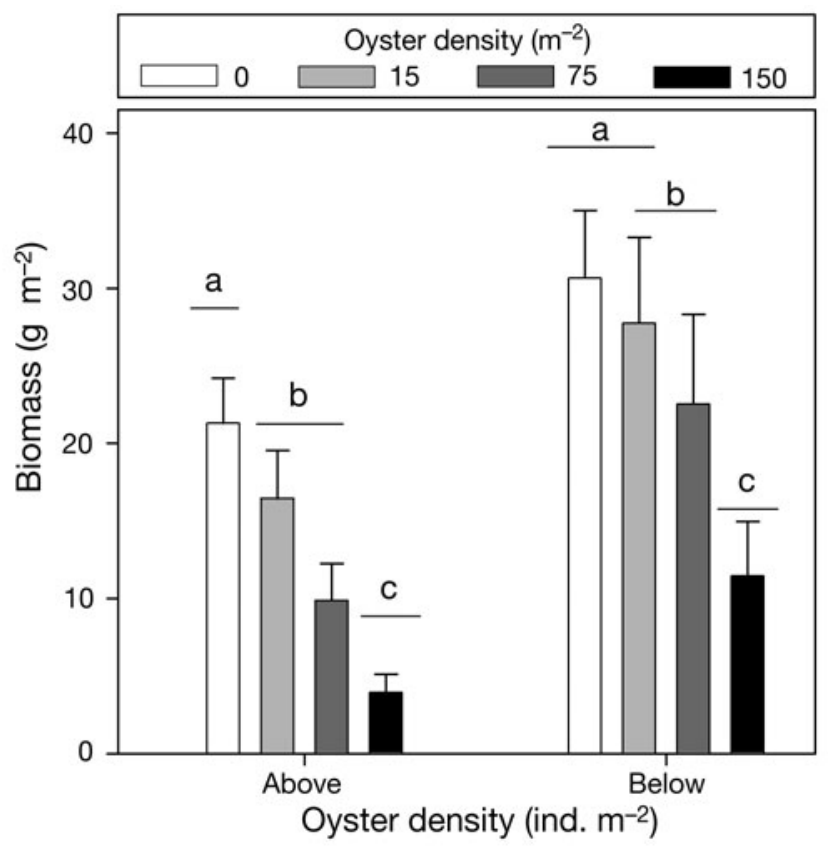

Fig. 2. Halodule wrightii. Average above- and belowground biomass $\left(\mathrm{g} \mathrm{m}^{-2}\right)$ with all dates and study blocks pooled. Letters indicate significant differences between treatments. Both above- and belowground biomass significantly decreased with increasing oyster density 
In the fall of 2004, there was a significant effect of oyster density $(p=0.004)$ and date $(p=0.000)$ on shoot density in Block 1 (Fig. 3). There was no significant difference shown between control, low, and medium density treatments, but the high density treatment did show significantly lower shoot density than both control and low density treatments ( $\mathrm{p}=$ 0.0247 and 0.004 , respectively). There was no difference shown between medium and high density treatments in Block 1. In Block 2 there was a significant effect of oyster density ( $p=0.017)$, date $(p=0.002)$, and interaction $(p=0.008)$. Control plots were not significantly different from medium and low density treatments, but were significantly higher than in the high density plots $(p=0.055)$. Low density treatments were not significantly different from medium and high density treatments, but medium density plots did show a significantly higher shoot density than high density treatments $(p=0.0013)$. In the spring of 2005, shoot density showed a significant effect of oyster density $(p=0.000)$ and date $(p=0.000)$ for Blocks 1 and 2 (Fig. 3). In both blocks there were no significant difference between control, low and medium density treatments, but there was a significant decrease in shoot density at the high density treatment level ( $\mathrm{p}=$ 0.000 for all comparisons).

\section{Oyster impact}

TSS were sampled on 29 October 2004, 28 February 2005, and 2 June 2005. A 3-way blocked ANOVA revealed no significant effects of oyster density $(\mathrm{p}=$ $0.739)$, date $(p=0.345)$, or block $(p=0.376)$ on TSS. While there was a significant effect of date on percentage light transmittance $(p=0.021)$, there was no significant effect for either oyster density $(p=0.133)$ or block $(\mathrm{p}=0.078)$.

An ANOVA examining epiphyte loading showed a significant effect for date $(p=0.003)$, block $(p=0.006)$, and the date $\times$ block interaction term $(p=0.007)$. However, it showed no significant effect of oyster density $(p=0.112)$, and the data showed no consistent trend amongst sampling date.

Porewater nutrients were sampled on 16 November 2004, 9 March 2005, and 21 July 2005 (approximately 1, 5, and 9 mo after oysters were deployed). An ANOVA revealed a significant effect of oyster density $(p=0.000)$, and a borderline significant effect of block $(p=0.056)$ on $\mathrm{PO}_{4}$ levels in the porewater (Fig. 4). There was no significant effect of date on porewater $\mathrm{PO}_{4}$ concentrations $(\mathrm{p}=0.315)$. There were no differences in $\mathrm{PO}_{4}$ concentrations between the control $\left(0\right.$ oysters $\mathrm{m}^{-2}$ ) and low density (15 oysters $\mathrm{m}^{-2}$ ) treatments $(\mathrm{p}>0.05)$, but there were signifi-

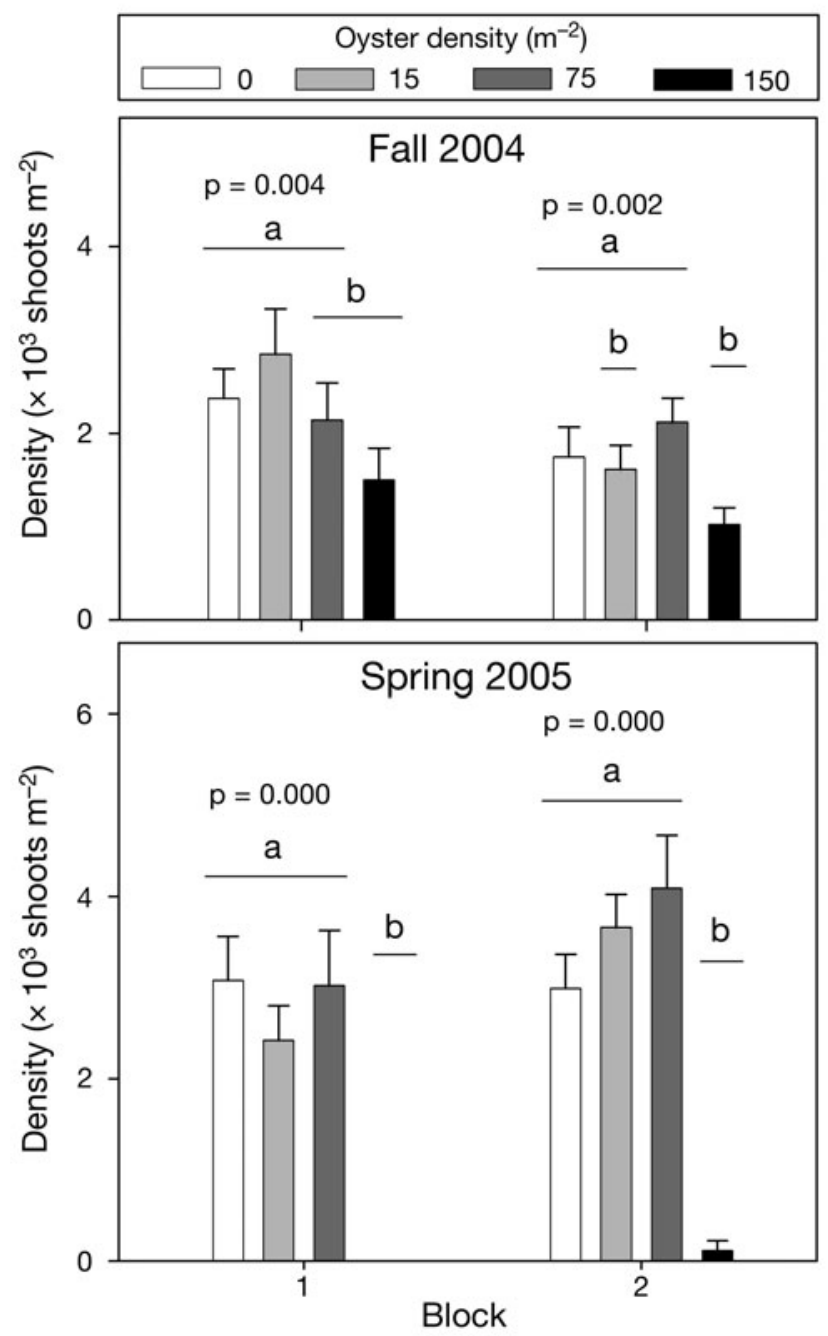

Fig. 3. Halodule wrightii. The effect of oyster density on shoot density (mean + SE) from 2004 and 2005. Study areas (Blocks 1 and 2) are separated due to significant interactions between block and date. Letters indicate significant differences between oyster densities. p-values indicate the effect of oyster density on no. of shoots $\mathrm{m}^{-2}$ within each block

cantly higher $\mathrm{PO}_{4}$ concentrations in the medium ( 75 oysters $\mathrm{m}^{-2}$ ) and high (150 oysters $\mathrm{m}^{-2}$ ) treatments when compared to the control $(\mathrm{p}=0.0114$ and 0.003 , respectively). However, the oyster density treatments themselves (low, medium and high) showed no significant difference in $\mathrm{PO}_{4}$ concentration between densities ( $\mathrm{p}>0.05$ ). For $\mathrm{NH}_{4}$ porewater concentrations (Fig. 4), an ANOVA showed a significant effect for all of the predictors (oyster density, block, and date; $\mathrm{p}=$ 0.000). While control treatments were not significantly different from the low density treatments, the medium and high densities showed significantly higher porewater concentrations of $\mathrm{NH}_{4}$ than the controls ( $p=0.000$ for both). Porewater concentrations of 

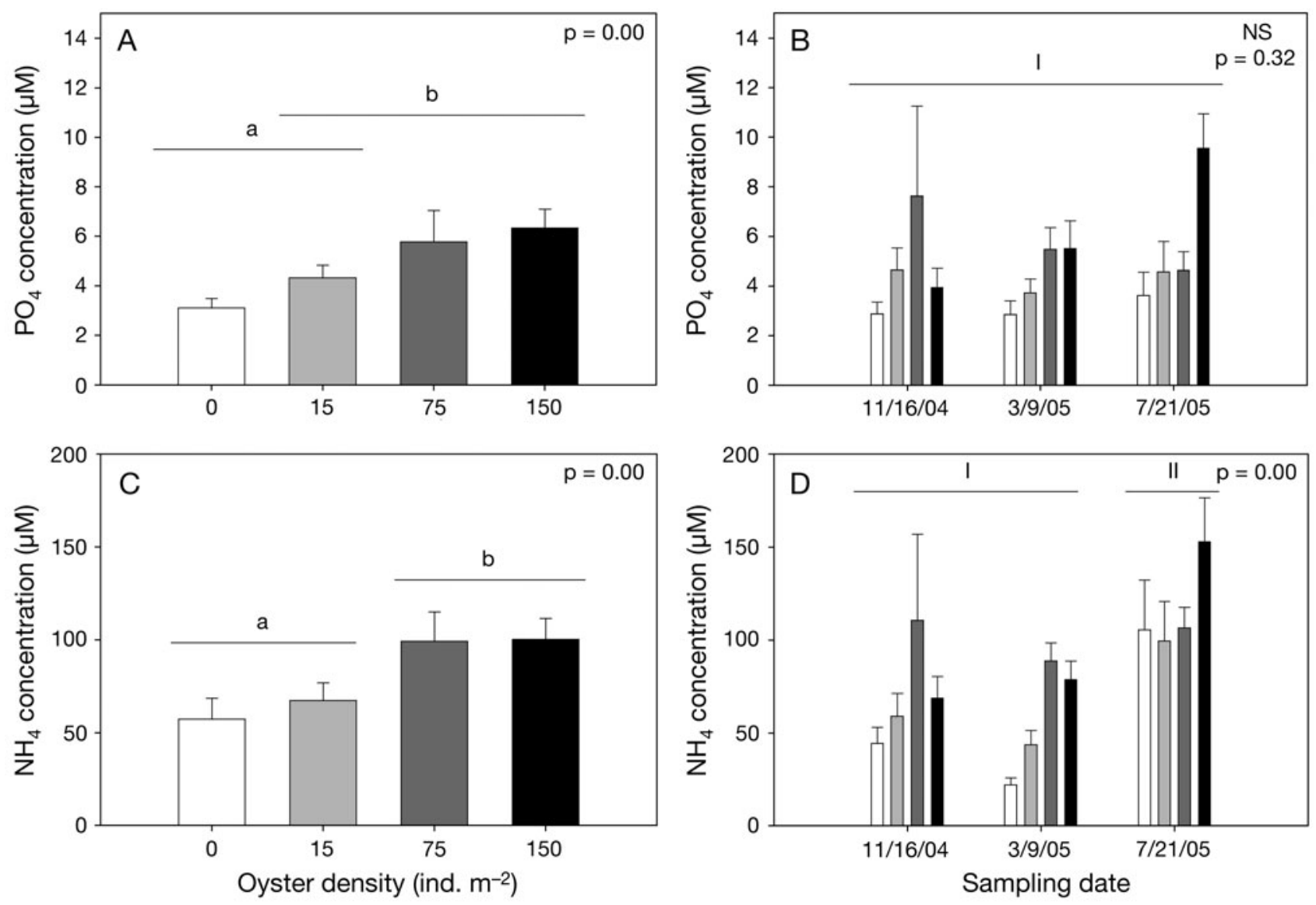

Fig. 4. Halodule wrightii. The effect of (A) oyster density and (B) date on porewater concentrations $(\mu \mathrm{M})$ of $\mathrm{PO}_{4}$ and $(\mathrm{C})$ oyster density and (D) date on porewater concentrations of $\mathrm{NH}_{4}$. Values are mean $+\mathrm{SE}$. Different letters indicate significant differences $(p<0.05)$ between oyster treatments. Different Roman numerals indicate significant differences $(p<0.05)$ between sampling dates

$\mathrm{NH}_{4}$ in medium and high density treatments were also significantly higher than in the low density treatments $(p=0.0151$ and 0.0065). However, porewater concentrations between medium and high oyster densities were not significantly different from each other $(\mathrm{p}=0.992)$

Sulfide levels in the sediments were also measured in September 2005, and the mean concentration in the control treatment was $204 \mu \mathrm{M}$, while the high density treatments had a mean concentration of $225 \mu \mathrm{M}$. There was no significant difference between the treatments $(\mathrm{p}=0.259)$.

Despite the significant increases in $\mathrm{NH}_{4}$ and $\mathrm{PO}_{4}$ concentrations in the sediment porewater, there was no significant effect of oyster density on $\mathrm{C}: \mathrm{N}, \mathrm{C}: \mathrm{P}$, or $\mathrm{N}$ :P ratios in seagrass tissue $(\mathrm{p}>0.05)$. There was a significant effect of date $(p=0.000)$ on $C: N$ ratios, however, with a decrease in the ratio between the first sampling date and the final 3 dates, indicating that plants were taking up more $\mathrm{N}$ later in the sampling season.

\section{DISCUSSION}

With the exception of Block 1 in the spring of 2005 (Fig. 1), addition of intermediate oyster densities resulted in significant increases in Halodule wrightii growth rate. Maximum growth rates were seen in the medium and low density treatments, while higher densities resulted in growth rates that were either similar to, or not significantly different from, the controls. Shoot density consistently decreased significantly with increasing oyster density.

This experiment confirms findings from previous studies, in showing that bivalves may impact sediment nutrient dynamics and increase porewater concentrations of nitrogen and phosphorus (Bertness 1984, Reusch et al. 1994, Peterson \& Heck 2001a, Newell et al. 2002). However, we found little evidence that oysters in close proximity to submerged aquatic vegetation enhanced light availability for adjacent plants. Epiphyte loads and TSS did not vary with oyster density; thus, fertilization of the sediment porewater by 
oyster feces and pseudofeces is the most likely mechanism influencing plant response.

Build-up of sediment organics may also explain the declines seen in shoot density and growth rate at high oyster densities. The sediment exuded a strong sulfur odor in the high density oyster treatments, leading to speculation that sulfide accumulation was the causative factor of decreasing shoot density and shoot growth rate. Increased supply of carbon to the sediment can increase microbial community metabolism, leading to depletion of sediment $\mathrm{O}_{2}$ and increased sulfate reduction rates (Terrados et al. 1999). High densities of oyster would also physically restrict water exchange with the sediment, further exacerbating the process of sulfide build-up. Many species of seagrasses and wetland macrophytes are negatively affected by increasing levels of sediment sulfide (Cline 1969, Koch et al. 1990, Carlson et al. 1994, Goodman et al. 1995, Terrados et al. 1999). When porewater sulfide occurs in high concentrations, it may diffuse through root tissue, thereby reducing carbon production and eliminating the carbon reserves critical to plant survival, especially if the plant is under stress from other perturbations (Terrados et al. 1999, Koch \& Erskine 2001, Holmer et al. 2005). In a species such as Halodule wrightii, which has extremely low C reserves (Hauxwell et al. 2001), the effects of sulfide could cause a dramatic response in growth rate and shoot density, such as was observed in this experiment. Further, studies have demonstrated that sulfur accumulates in root tissues, and when multiple stressors are also present, seagrass growth is significantly reduced (Holmer et al. 2005). The values measured in this experiment were not significantly different among treatments ( $p=0.259)$, but may not have accurately reflected the conditions during the bulk of the experiment, as we were forced to sample after Hurricane Katrina (September 2005). It is likely that sediment sulfide concentrations were affected by the storm. Though we were unable to satisfactorily resolve the role of sediment sulfide, the issue warrants further study.

The results of this study suggest that the impact of oyster addition to a system may depend on both distribution and spatial scale. Previous modeling experiments (Newell \& Koch 2004) assumed an even distribution of oysters throughout the system (as was also the case in this experiment); this is not entirely realistic, as oysters tend to aggregate in clusters. However, it is likely that restoring oyster reefs to historical population levels would produce an increase in larval supply to the system, thereby increasing the incidence of isolated clumps and individual oysters, which would more closely reflect the conditions of our experiment. It has been shown that on a small scale (on the order of $\mathrm{cm}$ to $\mathrm{m}$ ) seagrasses in association with oysters must con- tend with the effects of nutrient enrichment, space competition, and possibly sulfide toxicity, the effects of which can be either negative or positive depending on oyster density. Further experiments (D. M. Booth unpubl.) suggest that nutrient effects do not extend more than a few meters from the actual oyster aggregation itself, and consequently any benefits (or detriments) of nutrient addition are likely to be restricted to those grasses very near oyster clumps or reefs. Seagrasses in close proximity to oysters did not receive an immediate benefit in increased water clarity, but light should be addressed on a wider scale, as benefits are likely to be downstream of the oyster aggregation (10s of meters), or within a tidal creek or estuary (100s of meters). Earlier studies showed that oysters may affect water column clarity on an ecosystem-wide scale (Newell 1988, Mann 2000, Newell \& Koch 2004), and these effects may indeed result in benefits for seagrasses.

With the decline of seagrass populations worldwide contributing to many far-reaching negative effects (Orth et al. 2006), it is becoming increasingly important that ways are found to effectively repair and restore degraded seagrass ecosystems. Seagrass transplantation is currently the most widely used method of restoration, but is subject to limited success due to the stress the process causes to plants. Sediment fertilization has been suggested as a method by which the growth of seagrass in restoration efforts may be enhanced (Kenworthy \& Fonseca 1992, Peralta et al. 2003). As oysters can mitigate water turbidity, increase light penetration in shallow systems, and increase sediment nutrient availability, concurrent seagrass and oyster reef restoration has the potential to enhance seagrass establishment. During the early stages of establishment after transplantation, shoots are especially vulnerable to nutrient limitation due to the disturbance to the rhizosphere that hinders normal nutrient cycling and regeneration (Kenworthy \& Fonseca 1992) and oysters could alleviate this nutrient limitation. However, the potential for negative effects from oysters on the small scale shown here should be carefully considered before bivalve addition is considered a viable seagrass restoration method.

Acknowledgements. We acknowledge the Dauphin Island Sea Lab and the University of South Alabama for providing research facilities and funding for this project. We thank S. Powers and M. Posey for their guidance, and for rendering invaluable comments on this experiment. We also thank the numerous graduate students, techs, interns, and REUs that helped in the field and lab, and without whom nothing would have been accomplished: L. Baggett, M. Johnson, S. Davis, D. Byron, R. Shiplett, A. Hunter, A. Anton-Gamazos, R. Moody, C. Steeves, T. McGovern, S. Williams, K. McKay, C. Newton, 
K. Merkins, J. Koeppel, M. Kent, M. Finnegan, C. Harris, and D. Baggert. Finally, we thank L. Linn, D. Husband, and Dr. R. Kiene for their help with the nutrients and sulfide chemistry.

\section{LITERATURE CITED}

Bertness MD (1984) Ribbed mussels and Spartina alterniflora production in a New England salt marsh. Ecology 65: 1794-1807

Biggs RB, Howell BA (1984) The estuary as a sediment trap: alternate approaches to estimating its filtering efficiency. In: Kennedy VS (ed) The estuary as a filter. Academic Press, Orlando, FL, p 107-129

Breitburg DL, Palmer MA, Loher T (1995) Larval distributions and the spatial patterns of settlement of an oyster reef fish: responses to flow and structure. Mar Ecol Prog Ser 125: 45-60

Carlson PR, Yarbro LA, Barber TR (1994) Relationship of sediment sulfide to mortality of Thalassia testudinum in Florida Bay. Bull Mar Sci 54:733-746

Cline JE (1969) Spectrophotometric determination of hydrogen sulfide in natural waters. Limnol Oceanogr 14: 1489-1504

Dame RF (1979) The abundance, diversity and biomass or macrobenthos on North Inlet, South Carolina, intertidal oyster reefs. Proc Natl Shellfish Assoc 69:6-10

Dame RF, Zingmark R, Stevenson H, Nelson D (1980) Filter feeder coupling between the estuarine water column and benthic subsystems. In: Kennedy VS (ed) Estuarine perspectives. Academic Press, New York, p 521-526

> Dame RF, Spurrier JD, Wolaver TG (1989) Carbon, nitrogen and phosphorus processing by an oyster reef. Mar Ecol Prog Ser 54:249-256

Dame RF, Bushek D, Prins TC (2001) Benthic suspension feeders as determinants of ecosystem structure and function in shallow coastal waters. In: Reise K (ed) Ecological studies, Vol 151. Springer-Verlag, Berlin, p 11-37

Fourqurean JW, Zieman JC, Powell GVN (1992a) Phosphorous limitation of primary production in Florida Bay: evidence from $\mathrm{C}: \mathrm{N}: \mathrm{P}$ ratios of the dominant seagrass Thalassia testudinum. Limnol Oceanogr 37:162-171

Fourqurean JW, Zieman JC, Powell GVN (1992b) Relationships between porewater nutrients and seagrasses in a subtropical carbonate environment. Mar Biol 114: $57-65$

> Goodman JL, Moore KA, Dennison WC (1995) Photosynthetic responses of eelgrass (Zostera marina L.) to light and sediment sulfide in a shallow barrier island lagoon. Aquat Bot 50:37-47

Hauxwell J, Cebrián J, Herrera-Silveira JA, Javier Ramirez R, Arturo Zaldivar J, Gomez N, Aranda-Cirerol N (2001) Measuring production in Halodule wrightii: additional evidence suggests clipping underestimates growth rate. Aquat Bot 69: 41-54

Haven DS, Morales-Alamo R (1966) Aspects of biodeposition by oyster and other invertebrate filter feeders. Limnol Oceanogr 11:487-498

Holmer M, Frederiksen MS, Møllegaard H (2005) Sulfur accumulation in eelgrass (Zostera marina) and effect of sulfur on eelgrass growth. Aquat Bot 81:367-379

Howarth RW, Marino R (1988) Nitrogen fixation in freshwater, estuarine, and marine ecosystems: biogeochemical controls. Limnol Oceanogr 33(4):669-687

Howarth RW, Marino R, Lane J, Cole JJ (1988) Nitrogen fixation in freshwater, estuarine, and marine ecosystems: rates and importance. Limnol Oceanogr 33:669-687
Johnson MW, Heck KL, Fourqurean JW (2006) Nutrient content of seagrasses and epiphytes in the northern Gulf of Mexico: evidence of phosphorus and nitrogen limitation. Aquat Bot 85(2):103 -111

Kenworthy WJ, Fonseca MS (1992) The use of fertilizer to enhance growth of transplanted seagrasses Zostera marina L. and Halodule wrightii Ashers. J Exp Mar Biol Ecol 163:141-161

Koch MS, Erskine JM (2001) Sulfide as a phytotoxin to the tropical seagrass Thalassia testudinum: interactions with light, salinity and temperature. J Exp Mar Biol Ecol 266: 81-95

Koch MS, Mendelssohn IA, McKee KL (1990) Mechanism for the hydrogen sulfide-induced growth limitation in wetland macrophytes. Limnol Oceanogr 35:399-408

Mann R (2000) Restoring the oyster reef communities in the Chesapeake Bay: a commentary. J Shellfish Res 19: 335-339

May EB (1971) A survey of the oyster and oyster shell resources of Alabama. Ala Mar Resour Bull 4:1-53

Morgan MD, Kitting CL (1984) Productivity and utilization of the seagrass Halodule wrightii and its attached epiphytes. Limnol Oceanogr 29:1066-1076

Nelson KA, Leonard LA, Posey MH, Alphin TD, Mallin MA (2004) Using transplanted oyster (Crassostrea virginica) beds to improve water quality in small tidal creeks: a pilot study. J Exp Mar Biol Ecol 298(2):347-368

Newell RIE (1988) Ecological changes in Chesapeake Bay: Are they the result of overharvesting the American oyster, Crassostrea virginica? Understanding the estuary: advances in Chesapeake Bay research. Chesapeake Research Consortium Publication, Baltimore, MD, p 29-31

Newell RIE, Koch EW (2004) Modeling seagrass density and distribution in response to changes in turbidity stemming from bivalve filtration and seagrass sediment stabilization. Estuaries 27:793-806

Newell RIE, Cornwell JC, Owens MS (2002) Influence of simulated bivalve biodeposition and microphytobenthos on sediment nitrogen dynamics: a laboratory study. Limnol Oceanogr 47:1367-1379

> Orth RJ, van Montfrans J (1984) Epiphyte-seagrass relationships with an emphasis on the role of micrograzing: a review. Aquat Bot 18:43-69

Orth RJ, Carruthers TJB, Dennison WC, Duarte CM and others (2006) A global crisis for seagrass ecosystems. Bioscience 56:987-996

Peralta G, Bouma TJ, van Soelen J, Pérez-Lloréns JL, Herdández I (2003) On the use of sediment fertilization for seagrass restoration: a mesocosm study on Zostera marina L. Aquat Bot 75:95-110

Peterson BJ, Heck KL Jr (2001a) An experimental test of the mechanism by which suspension feeding bivalves elevate seagrass productivity. Mar Ecol Prog Ser 218:115-125

> Peterson BJ, Heck KL Jr (2001b) Positive interactions between suspension-feeding bivalves and seagrass - a facultative mutualism. Mar Ecol Prog Ser 213:143-155

Posey MH, Wigand C, Stevenson JC (1993) Effects of an introduced aquatic plant, Hydrilla verticillata, on benthic communities in the Chesapeake Bay. Estuar Coast Shelf Sci 37: 539-555

Powell GVN, Kenworthy WJ, Fourqurean JW (1989) Experimental evidence for nutrient limitation of seagrass growth in a tropical estuary with restricted circulation. Bull Mar Sci 44:324-340

Powell EN, Hofmann EE, Klinck JM, Ray SM (1992) Modeling oyster populations. I. A commentary on filtration rate: Is faster always better? J Shellfish Res 11:387-398 
Reusch TBH, Chapman ARO, Gröger JP (1994) Blue mussels Mytilus edulis do not interfere with eelgrass Zostera marina but fertilize shoot growth through biodeposition. Mar Ecol Prog Ser 108:265-282

Sharp JH (1974) Improved analysis for 'particulate' organic carbon and nitrogen from seawater. Limnol Oceanogr 19: 984-989

Solorzano L, Sharp JH (1980) Determination of total phosphorus in natural water. Limnol Oceanogr 25:756-760

Editorial responsibility: Richard Osman,

Edgewater, Maryland, USA
Terrados J, Duarte CM, Kamp-Nielsen L, Agawin NSR and others (1999) Are seagrass growth and survival constrained by the reducing conditions of the sediment? Aquat Bot 65:175-197

Tomasko DA, Dunton KH (1995) Primary production in Halodule wrightii: a comparison of techniques based on daily carbon budgets. Estuaries 18:271-278

Williams SL (1990) Experimental studies of Caribbean seagrass bed development. Ecol Monogr 60:449-469

Submitted: July 15, 2008; Accepted: June 16, 2009

Proofs received from author(s): August 21, 2009 